\title{
A Short Review on Milkfish (Chanos chanos)
}

\section{G. Ganesh ${ }^{1 *}$, B. Chamundeswari Devi ${ }^{2}$, D.R.K. Reddy ${ }^{1}$, Rajesh Debnath ${ }^{3}$, Gora Shiva Prasad ${ }^{3}$, A Srinivasa Rao ${ }^{4}$ and L.V. Naga Mahesh ${ }^{1}$}

${ }^{1}$ College of Fishery Science, S.V.V.U., Muthukur, Nellore, Andhra Pradesh, India

${ }^{2}$ Principle Scientist \& Univ. Head Fisheries Research Station, Kakinada, Andhra Pradesh, India

${ }^{3}$ Faculty of Fishery Science, W.B.U.A.F.S., Kolkata- 700094, West Bengal, India

${ }^{4}$ Scientist (Fishery Science) Krishi Vigyan Kendra, Undi, India

West Godavari, Andhra Pradesh, India

*Corresponding author

\section{A B S T R A C T}

\section{Keywords}

Fisheries, Milkfish, Polyculture and Biology

\section{Article Info}

Accepted:

10 November 2020

Available Online:

10 December 2020
The Fisheries sector is a dominant sector in India, providing employment to millions of people and contributes to the food security of the country. It is one of the leading food sectors in the world. The milkfish Chanos chanos, is an economically important cultured marine species, chief food source in Southeast Asia mainly in Taiwan, Indonesia and the Philippines. They are considered as sustainable and affordable species, which is suitable for polyculture with other species such as shrimp, catfish and tilapia and can tolerate a wide range of salinity. This review will provide an overview of the available potential resources for the culture, the biology of milkfish and culture of milkfish in a different system.

\section{Introduction}

Aquaculture is on the promising food sector in the world compare to all other animal protein food production (Meat and Milk). In 2018, aquaculture shares half to the overall total Global fish production. Fisheries and aquaculture play a major role in the human consumption, and per capita, fish consumption increased from the $13.4 \mathrm{~kg}$ (live weight equivalent) in $1986-1995$ to $20.5 \mathrm{~kg}$ in the year 2018 (F.A.O., 2020). It noted that World demand for fish, both as a source of food for human consumption and reduction to fishmeal is growing steadily. Extrapolation of trends advises that by the end of the first quarter of the century, farmed fish production will outstrip capture fishery production and will be the most important means of providing fish for food. All over the world fishing industry is facing a significant crisis with fish stocks declining. The list of depleting fish 
stocks is getting longer and longer every year. According to F.A.O., about $70 \%$ of the world's major species and eleven of the 15 major fishing areas are in the process of disappearing. This decline in the world fish supply is the result of overfishing, indiscriminate fishing methods and degradation of coastal and producer of fish through aquaculture in the world.

Milkfish (Chanos chanos) is one of the candidate essential euryhaline (Martinez et al., 2006; Yang et al., 2016) and brackish water finfish species being cultured in southeast India. During 2018 milkfish farming accounted 11 327.2thousand tones production which is $2.4 \%$ of total finfish produced globally from aquaculture (F.A.O., 2020). Naturally, milkfish fry occurs along the southeast coast of India is a relatively large number during the months of MarchJune and October-November (Jaikumar et al., 2013). Aquaculture of milkfish was begun in Indonesia over 500 years ago, followed by Taiwan and the Philippines. The milkfish is a marine inhabitant commercially cultured in brackish water ponds with different salinities (Kang et al., 2015) and oceanic waters as well as in hypersaline lagoons. In contrast, juvenile milkfish showed better F.C.R. in brackish water at (25\%) salinity, compared to a freshwater body (Jana et al., 2006).

Milkfish is a high-quality food fish with a rapid growth rate, and it is highly resistant to diseases. Some of the characters that make milkfish a desirable fish species to culture are: (i) herbivorous feeding habit, which ensures nutritional security with accessible farming technology and reduce the cost of production, (ii) It has higher growth rate than the other herbivorous species (iii) The species can be cultured with other cultivable species such as mullet, shrimps, etc., (iv) Under culture condition the species readily accept formulated diets, (v) the species has an attractive appearance which makes it potential live bait for tuna fishery, (vi) High fecundity, (vii) The species has an attractive economic value in the domestic markets of India (ANON, 2018).

\section{Biology}

Milkfish (Chanos chanos) is the solitary species in the family Chanidae and usually found in the clear, shallow, saline, warm waters above $20{ }^{\circ} \mathrm{C}$. Along the coasts of continents or islands, large coastal lagoons, tropical waters mainly where reefs are well developed. Adult and juvenile milkfish feed on a variety of foods depending on the type of environment and has a small toothless mouth. During the larvae, they mostly feed on zooplankton present in the water bodies. As they develop into juveniles they start to provide on benthic items associated with micro and meiofauna and the most common food items are cyanobacteria, diatoms, detritus, green algae and invertebrates such as small crustaceans and worms. Adult milkfish have a well-developed epibranchial organ, which is an extension of the alimentary canal, which allows to digest plant materials (Bagarinao et al., 1994). They breed nearshore, and shallow waters lay pelagic eggs. Fertilized eggs are spherical having a narrow perivitelline space, and their diameter ranges from 1.10 to $1.25 \mathrm{~mm}$. Its breeding season is longer near the equator. Milkfish may spawn more than once a year, and spawning usually takes places during the night. Spawning is highly seasonal and may be influenced by the lunar cycle (Bagarinao et al., 1994), and the optimum temperature for spawning occurs at $28^{\circ} \mathrm{c}$ (Martinez et al., 2006). The length of the spawning season may be affected by surface water temperature in certain areas (Bagarinao et al., 1994; Garcia, 1990). The larva entirely depends for five days on the yolk sac after hatching. 


\section{Available resources in India for milkfish culture}

In India, on a global scale, also, the decline of fish stocks has been a motivating factor for expanding the role of aquaculture (Celikkol et al., 2000). The systems of cage farming have an essential role in meeting the global demand for fish products (Frederickson et al., 2000). The marine fishery resources of India include a coastline of $8118 \mathrm{Km}$ with numerous creeks, huge areas of estuaries, lagoons and saline water areas, an Exclusive Economic Zone (EEZ) of 2.02 million $\mathrm{Km}^{2}$ (Consisting of 0.56 million sq. $\mathrm{km}$ on the east coast, 0.86 million sq. $\mathrm{km}$ on the west coast and $0.60 \mathrm{sq}$. $\mathrm{km}$ around the Andaman \& Nicobar Islands).There are also about 3.15 million hectare reservoirs, 2.25 million ha of lakes and ponds, 0.82 million ha of beels, oxbow lakes, derelict water bodies and 1.24 million ha of brackish water areas and 0.29 million ha of estuaries (Datta, 2011; Anonymous, 2020). These resources remain below the potential use and can be considered for converting in to successfully aquaculture ventures. Rational utilization of these potential resources for cage culture can considerably improve fish production in India (Rao, 2009).

\section{Grow-out culture of milkfish in the enclosure system}

Milkfish can be cultured in all the culture system viz. extensive, semi-intensive and intensive in ponds, pens or cages. The brackish water areas of India like Ghazni in Karnataka, Pokkali in Kerala, Chilka Lake in Odisha, Bheries in West Bengal, the extensive traditional milkfish farming were practised where the species solely depends on Lumut (Filamentous algae) and Lab-lab (Benthic algae).Milkfish has several advantages in the culture of the marine ecosystem, because of resistance to high salinity water and cultured easily compared to other marine species may be it feed on the wider range of feeding behaviour in natural and artificial feed and easily cultured with other species, no cannibalism was observed (Huniyah et al., 2015). Milkfish cultures in cages are characterized by intensive management procedure which includes high levels of inputs in small culture area like seeds and feeds.

The selected site should free from the pollution, secured from extreme weather condition, water temperature, depth of culture and protected from the poachers. Moreover, sediment and undigested or uneaten feed may alter the water quality parameters, which may cause harmful effect to not only cultured organisms but also to the animals living in submerged sediments such as polychaetes, marine worms. Fish grown in cages can be quickly graded if required.

The netting on the cages is partially pulled out of the water or, if steel cage netting is used, an inner capture net is used to concentrate the fish. Once the fish are crowded into a small area, they can be scooped or pumped from the water into a mechanical grader. Each farm has its management practices that dictate if and when grading is required (Glenn Schipp et al., 2007).

In the cage culture, stocking densities of species are highly variable, and little research was done to establish the optimum stocking densities for many species (Beveridge et al., 2004). Stocking density also depends on the carrying capacity of the cages. Optimal stocking density varies with pieces and sizes of fish stocked (Brown, 1946; Chua and Teng, 1979). In cage culture practice determination of the optimal stocking rate becomes an integral part because stocking density directly influences the growth rate of the cultured species (Kilambi et al., 1977). 
Culture of milkfish (Larval rearing and polyculture)

Milkfish is a day time feeder, and mostly it depends upon the external light (artificial or fluorescent light).Recently larval culture of milkfish was developed to reduce the larval mortality. They have concluded that better milkfish larval rearing is successful in yellow background tanks, whereas the white and blue tank showed lesser survival rate in the experiment might be due to the less feeding. The yellow tank can achieve improved, or mass seed production of milkfish may increase due to the higher scattering of light from its walls of the experimental tank (Bera et al., 2019).

On the other hand, Eldani and Primavera (1981) studied the effect of different stocking combinations on growth, production and survival of milkfish (Chanos chanos) and prawn (Penaeus monodon) in polyculture in brackishwater ponds. They recorded that average survival rates were high for milkfish ranging from 90 to $96 \%$, but only $50 \%$ in the case of prawn. The competition index between milkfish and prawn at the given stocking combinations was negative, indicating a positive, advantageous influence of prawn on milkfish production. Weight gain of milkfish doesn't depend upon the stocking densities (Teshima et al., 1984), whereas the increase $(\%)$ in body length $(\mathrm{P}<0.01)$ has been observed at a lower stocking density. Higher growth of milkfish recorded in the pond in contrast to other crustaceans and piscine species (Eldani and Primavera, 1981; James et al., 1984); this is why it has been so successfully cultured for centuries. Growth rates of juvenile milkfish vary considerably depending on genetic factors, environmental factors such as food, competitors, pests, predators, dissolved oxygen, temperature, salinity, $\mathrm{pH}$, toxicants and stock manipulation techniques such as initial stock size, stocking density, feeding, duration of culture, mono or polyculture with other species. Growth and survival parameters are among the tools used to evaluate culture techniques and innovations, so data for juvenile milkfish abound (Eldani and Primavera, 1981; Gerochi et al., 1988).

The negative allometric growth pattern was documented during the cultivation of milkfish and sea cucumber by multi-trophic sea farming. They have advised that a greater extent of weight gain in milkfish occurs mainly by body length, while environmental and age factors factor account only $12 \%$ in fish weight gain (Surbakti et al., 2020). Baliao et al., (1987) conducted a study on milkfish with stocking densities of 15, 20, 25, and 30fingerlings $/ \mathrm{m}^{2}$ subjected to 6-month stunting. These finding showed a positive result at 20 fingerlings $/ \mathrm{m}^{2}$, and no significant difference was observed between 15 and 25 fingerlings $/ \mathrm{m}^{2}$. While in other findings concluded that improved survival of milkfish in the nursery phase to $50-60 \%$ at a stocking density of 25-50 fry $/ \mathrm{m}^{2}$ had been found (Villegas and Bombeo, 1981). In floating cages, juvenile milkfish grow faster in $5 \mathrm{~m}$ diameter cages than in $3 \mathrm{~m}$ diameter cages (Juario et al., 1979). Milkfish survival during the nursery period tends to be lower (40-70\% over 35-45 days) (Villegas and Bombeo, 1981; Carreonn et al., 1984) than during the grow-out period (75-100\% over 90-120 days) (Pudadera and Lim 1980; Eldani and Primavera 1981; Otubusin and Lim 1985; Gerochi et al., 1988). In another study Milkfish fry were (5-6cm with 0.9 to $1 \mathrm{~g}$ size) collected from the wild and experimented with three systems such as clear water and biofloc rearing done in indoor condition whereas, the traditional system of culture in the outdoor experiment. They have documented that better fingerling size, low F.C.R. and High survivability obtained in biofloc than the other two culture system (Sontakke and Haridas, 2018) may be due to 
the digestion efficiency increased in the milkfish, similar to other study conducted in different variety of aquatic fish species.(Luo et al., 2014; Verma et al., 2016; Zhang et al., 2016).

Future prospective and conclusion are as follows:

Milkfish is an ideal brackish water species for diversification of aquaculture sector of India. There is no incidence of milkfish disease outbreak has been noticed till now, which gives confidence to the farmers for adaption to culture. The fingerlings of milkfish have very high demand in India due to its potential to attract tuna. In India, several seed production enterprises, brood fish supplier, feed manufacturing company etc. have already been developed, which indicates its rapid rate of adaption by the Indian farmers. Milkfish culture in India is revolutionizing the brackish water fish farming mainly due to high profit, low cost of production and its eco-friendly culture system. ICAR-CIBA has taken the initiatives on seed production and captive brood-stock of milkfish in project mode at Muttukadu hatchery to popularize more India (ANON, 2018).

\section{References}

ANON, 2018. A guide to Milkfish (Chanos chanos) Aquaculture. I.C.A.R.- Central Institute of Brackishwater Aquaculture. p. 5-18.

Anonymous, 2020. National Fisheries Development Board (N.F.D.B.), Department of Fisheries, Ministry of Fisheries, Animal Husbandry \& Dairying, Government of India. Available from http://nfdb.gov.in/aboutindianfisheries.htm. Accessed in June 2020.

Bagarinao, T., 1994. Systematic, distribution, genetics and life history of milkfish,
Chanos chanos. Environmental Biology

of Fishes. 39(1): 23-41.

Baliao, D. D., Franco, N. M. and Agbayani, R. F. 1987. The economics of retarding milkfish growth for fingerling production in brackishwater ponds. Aquaculture. 62(3-4): 195-205.

Bera, A., Kailasam, M., Mandal, B., Sukumaran, K., Makesh, M., Hussain, T. and Vijayan, K. K. 2019. Effect of tank colour on foraging capacity, growth and survival of milkfish (Chanos chanos) larvae. Aquaculture. $512,734347$.

Beveridge, M., 2004. Cage Aquaculture. Blackwell Publishing. Third Edition, pp. 111-158.

Brown, M. E., 1946. The growth of brown trout (Salmo trutta Linn.): I. Factors influencing the growth of trout fry. Journal of Experimental Biology. 22(34): 118-129.

Carreon, J.A., L.V. Laureta, F.A. Estocapio, and T.U. Abalos. 1984. Milkfish seedling survival in raceways of freshwater recirculating systems. Aquaculture. 36(3): 257-272.

Celikkol, B., Baldwin, K., Steen, R., Michelin, D., Muller, E. and Lavoie, P. 2000. Open ocean aquaculture engineering: Mooring \& net pen deployment. Marine Technology Society Journal. 34(1): 53-58.

Chua, T. E., and Teng, S. K., 1979. Relative growth and production of the estuary grouper Epinephelus salmoides under different stocking densities in floating net-cages. Marine biology. 54(4): 363372.

Datta, S., 2011. Inland Fisheries Resources of India. C.I.F.E., Kolkata Centre, Article in Inland Water Biology.

Eldani, A., and Primavera, J. H. 1981. Effect of different stocking combinations on growth, production and survival of milkfish (Chanos chanos Forskal) and 
prawn (Penaeus monodon Fabricius) in polyculture in brackishwater ponds. Aquaculture. 23(1-4): 59-72.

F.A.O. 2020. The State of World Fisheries and Aquaculture 2020. Sustainability in action. Rome. https://doi.org/10.4060/ca9229en

Fredriksson, D. W., Muller, E., Baldwin, K., Robinson Swift, M. and Celikkol, B. 2000. Open ocean aquaculture engineering: system design and physical modeling. Marine Technology Society Journal. 34(1): 41-52.

Garcia, L. M. B., 1990. Fishery biology of milkfish (Chanos chanos Forskal). In Proceedings of the Regional Workshop on Milkfish Culture Development in the South Pacific. Accessed October (Vol. 10, p. 2005).

Gerochi, D. D., Lijauco, M. M., and Baliao, D. D. 1988. Comparison of the silo and broadcast methods of applying organic fertilizer in milkfish, Chanos chanos (Forsskal), ponds. Aquaculture. 71(4): 313-318.

Huniyah, A., Alamsyah, M. A. and Pursetyo, K. T. 2015. Financial Analysis of Fish Enlargement Milkfish (Chanos chanos) in Pond with Traditional Farming and Monoculture-Polyculture System in Mulyorejo Surabaya East Java J. Ilmiah Perikanan dan Kelautan. 7, 169-176.

Imelda, J., Joseph, V. E. and Susmitha, V. 2009. Course manual: National training on cage culture of seabass. Pp. 14-23.

Jaikumar, M., Suresh Kumar, C., Robin, R. S., Karthikeyan, P. and Nagarjuna, A. 2013. Milkfish Culture: Alternative Revenue for Mandapam Fisherfolk, Palk Bay, Southeast Coast of India. International Journal of Fisheries and Aquaculture Sciences. 3 (1):31- 43.

James, P. S. B. R. and Rengaswamy, V. S. 1984. Further observations on polyculture of finfishes and prawns in saltwater ponds and in a net-pen at
Mandapam. Indian Journal of Fisheries. 31(1): 31-46.

Jana, S. N., Garg, S. K. and Patra, B. C. 2006. Effect of inland water salinity on growth performance and nutritional physiology in growing milkfish, Chanos chanos (Forsskal): field and laboratory studies. Journal of Applied Ichthyology. 22(1): 25-34.

Juario, J. V., Natividad, M., Quinitio, G. and Banno, J. 1979. Experiments on the induced spawning and larval rearing of the milkfish, Chanos chanos (Forsskal) in 1979. S.E.A.F.D.E.C. Aquaculture Department Quarterly Research Report. 3(2), 1-3.

Kang, C. K., Chen, Y. C., Chang, C. H., Tsai, S. C. and Lee, T. H. 2015. Seawateracclimation abates cold effects on $\mathrm{Na}$, $\mathrm{K}+$-ATPase activity in gills of the juvenile milkfish, Chanoschanos. Aquaculture. 446, 67-73.

Kilambi, R. V., Adams, J. C., Brown, A. V. and Wickizer, W. A. 1977. Effects of stocking density and cage size on growth, feed conversion, and production of rainbow trout and channel catfish. The Progressive Fish-Culturist. 39(2): 62-66.

Luo, G., Gao, Q., Wang, C., Liu, W., Sun, D., Li, L. and Tan, H. 2014. Growth, digestive activity, welfare, and partial cost-effectiveness of genetically improved farmed tilapia (Oreochromis niloticus) cultured in a recirculating aquaculture system and an indoor biofloc system. Aquaculture. 422, 1-7.

Martinez, F. S., Tseng, M. C. and Yeh, S. P. 2006. Milkfish (Chanos chanos) culture: situations and trends. J. fish. Soc. Taiwan. 33(3): 229-244.

Otubusin, S.O., and C. Lim. 1985.The effect of duration of feeding on survival, growth and production of milkfish, Chanos chanos (Forsskal) in brackishwater ponds in the Philippines. 
Aquaculture. 46(4):287-292.

Pudadera, B. Jr., and C. Lim. 1980. Evaluation of milkfish (Chanoschanos Forsskal) and prawn (Penaeus monodon Fabricius) in polyculture systems. S.E.A.F.D.E.C. Aquaculture Dept. Quart. Res. Rep. 4(3): 1-6.

Rao, G.S., 2009. Overview on mariculture and the opportunities and challenges of cage culture in India.

Schipp, G., Bosmans, J. and Humphrey, J. 2007. Barramundi farming handbook. Department of Primary Industry, Fisheries and Mines, Northern Territory Government.

Sontakke, R., and Haridas, H. 2018. Economic viability of biofloc based system for the nursery rearing of milkfish (Chanos chanos). International Journal of Current Microbiology and Applied Sciences. 7, 2960-2970.

Surbakti, J. A., Dewi, I. A. L., Alamsjah, M. A. and Lamid, M. 2020. Relationship of long weight between milkfish (Chanos chanos forsskal) and sea cucumber (Holothuria leucospilot) that are multitrophic sea farming. E\&ES, 441(1): 012143.

Teshima, S. I., Kanazawa, A. and Kawamura, G. 1984. Effects of several factors on growth of milkfish (Chanos chanos Forskal) fingerlings reared with artificial diets in aquaria. Aquaculture. 37(1): 39-50.

Verma, A., Rani, A. B., Rathore, G., Saharan, N. and Gora, A. H. 2016. Growth, nonspecific immunity and disease resistance of Labeo rohita against Aeromonas hydrophila in biofloc systems using different carbon sources. Aquaculture. 457, 61-67.

Villegas, C.T., and I. Bombeo. 1981. Effects of increased stocking density and supplemental feeding on the production of milkfish fingerlings. S.E.A.F.D.E.C. Aquaculture Dept. Quart. Res. Rep. 5(2):7-11.

Yang, W. K., Chung, C. H., Cheng, H. C., Tang, C. H. and Lee, T. H. 2016. Different expression patterns of renal $\mathrm{Na}+/ \mathrm{K}+$-ATPase $\quad \alpha$-isoform-like proteins between tilapia and milkfish following salinity challenges. Comparative Biochemistry and Physiology Part B: Biochemistry and Molecular Biology. 202, 23-30.

Zhang, N., Luo, G., Tan, H., Liu, W. and Hou, Z. 2016. Growth, digestive enzyme activity and welfare of tilapia (Oreochromis niloticus) reared in a biofloc-based system with polyBhydroxybutyric as a carbon source. Aquaculture. 464, 710-717.

\section{How to cite this article:}

Ganesh, G., B. Chamundeswari Devi, D.R.K. Reddy, Rajesh Debnath, Gora Shiva Prasad, A Srinivasa Rao and Naga Mahesh, L.V. 2020. A Short Review on Milkfish (Chanos chanos). Int.J.Curr.Microbiol.App.Sci. 9(12): 899-905. doi: https://doi.org/10.20546/ijcmas.2020.912.108 